\title{
Modelling of Diversified Development of Rural Areas
}

\author{
Merenkova I.* \\ Department of Economic Analysis, Statistics and Applied \\ Mathematics \\ Voronezh State Agrarian University named after Emperor \\ Peter the Great \\ Voronezh, Russia \\ e-mail: upr-nii@yandex.ru
}

\author{
Zakupnev S. \\ Department of Economic Analysis, Statistics and Applied \\ Mathematics \\ Voronezh State Agrarian University named after Emperor \\ Peter the Great \\ Voronezh, Russia \\ e-mail: zaksl@yandex.ru
}

\author{
Agibalov A. \\ Department of Finance and Credit \\ Voronezh State Agrarian University named after Emperor \\ Peter the Great \\ Voronezh, Russia \\ e-mail: agi-64@mail.ru \\ Vorobyev S. \\ Department of Accounting and Audit \\ Voronezh State Agrarian University named after Emperor \\ Peter the Great \\ Voronezh, Russia \\ e-mail:vsv47@mail.ru
}

\begin{abstract}
The need for diversification as an effective tool for the rural area development is reasoned and it is substantiated that the transition from the sector-specific structure of the rural economy to the multi-sectoral economy involves the development of new activities, more rational use of the available resources of rural areas, making them more sustainable and competitive. A critical interpretation of the theoretical approaches to substantiating a promising model of rural development was carried out and their options were analyzed. It is proved that rural territories are a complex socio-economic system, and the process of their diversification is conditioned by the object-subject relationship. Based on the implementation of the functional-structural-target approach, the model of diversified rural economy has been developed, taking into account the degree to which some of other sector prevails in its structure, as well as their various combinations. The promising areas of rural economy restructuring based on the expert assessment have been identified. Structurally, the model links the main areas and activities: agricultural (traditional and lost); nonagricultural (industry and construction, forestry, arts and crafts); service sector (education, healthcare, recreation, consumer services). The proposed model of diversified rural development allows an objective assessment of the potential and level of diversification of the rural economy, and the use of assessment results will facilitate the adoption of informed management decisions and the formation of rural policies at the regional and local levels.
\end{abstract}

Keywords - rural areas, multi-functionality, diversification, rural economy structure, diversified development model, sectorspecific and multi-sectoral economy format.

\section{INTRODUCTION}

One of the priority strategic tasks aimed at the reduction of the high spatial differentiation of rural territories is their diversification, carried out by involving unused resource reserves in the circulation and developing industries based on this, whose products have stable market demand [1, 13].
In recent decades, rural areas, despite the successes achieved in agricultural production, are facing new socio-economic and environmental problems. Agriculture is, in its essence, a lifesupporting branch of the national economy and helps to increase the country's food security, but its role has noticeably decreased over the years of reform in the Russian economy. If in 1990 the share of agriculture in Russian gross domestic product was about $16.0 \%$, in 2016 it was only $4.4 \%$ [5].

The general structural crisis has led to the decline in the number of jobs not only in agriculture, but also in industry, while the service sector is not developing so dynamically as to provide rural residents with employment opportunities [2]. At the same time, agriculture continues to be a system-forming sector of the rural economy, which is due to both the peculiarities of the rural mentality and lifestyle of the villagers (35.0\% of the rural population associate their life and work exclusively with agricultural activity), and the lack of favorable conditions for the development of alternative rural activities [14].

In this regard, for solving the indicated problems, the transition of rural territories to the path of diversified development and the creation of the greatest possible variety of economic forms and types of activity in the countryside, the integrated use of the territory's resources and the provision of rural employment are of particular importance [3].

\section{LITERATURE REVIEW}

If we view the rural areas as a complex socio-economic system, including multifunctional and interconnected social, economic, and environmental blocks, which can serve as a basis for determining the necessary conditions for rural diversification [12], then the modeling of the diversified rural development requires the use of appropriate tools [7, 11]. 
Informal models include sectoral, redistributive, and territorial ones, which in turn are consistent with the basic concepts of rural development [4].

The sectoral model was based on a concept that placed the agricultural sector at the forefront, the key idea of which is the assumption that progress in the development of agriculture and agribusiness will lead to the development of rural areas [6].

The redistribution model is based on the concept of reducing the differentiation between depressed and developed rural areas due to the redistribution of financial support funds in the form of direct compensations, which are aimed at neutralization of the adverse factors, as well as grants allocated for structural adjustment of the rural economy.

The territorial model is implemented on the basis of the concept of rural development, the purpose of which is directly related to the integrated use of the diverse natural resource potential with the integration of production at the local level. The budgetary support is aimed at expanding the diversification of income of agricultural companies and the development of non-agricultural activities, infrastructure, and services for the local population [8]. Most typically, such models are based on the development of all sectors of the economy (industry, agriculture, construction, rural tourism; industry and agriculture; construction and agriculture) and on the development of various agricultural production sectors (organizations, farmers, and private small holdings; only organizations; organizations and small holdings, or farmers and private small holdings).

When developing a model of diversified development of the rural economy, it should be taken into account that, in general, the sectoral model of rural development is being implemented in the country, which is inherently imperfect, and, by and large, inefficient. Therefore, reorientation of the sectoral model into the territorial one with gradual transition from the sector-specific model of the rural economy to a multi-sectoral one based on the social approach and taking into account the natural, productive and resource characteristics of the rural areas is required [9].

\section{RESULTS}

To build the model of diversified rural development, we used the methodology and the existing economy structure in rural areas [15], which allows assessing not only the level and potential of rural diversification based on the existing natural and social potential of the territory, but also identifying all possible options for further development of the rural areas, which is directly related to the rational and efficient distribution of resources between alternative areas of rural development.

This procedure was tested in the Voronezh region, and its results showed that all rural territories of the districts were almost evenly distributed among the identified groups of diversification levels (critical, low, moderate, high).

The first group with high diversification level included 8 districts in which there are all prerequisites for the development of rural diversification, which will not only increase the number of jobs and income level of the rural population, but also bring the districts to a new level of development.
The second group with moderate diversification level included 7 districts. In the rural economy of these territories, the process of forming the conditions and potential required for diversification has been started. At the same time, it must be taken into account that the regional authorities are ready for the transition to the sustainable development of rural territories through the launch of diversification processes in the countryside.

The third group with low diversification level was formed by 10 districts. Diversification is not among the key directions in the development of rural territories of this group. District and local authorities are quite satisfied with the existing structure of the rural economy.

The fourth group with critical diversification level included 6 districts in which the prerequisites for the development of diversification processes in rural areas were not formed.

The obtained results allow concluding that in the Voronezh region; almost $50.0 \%$ of all rural municipalities are ready to develop diversification in the countryside, which allows proceeding to the modeling of these processes for rural areas.

Previous to this research we had examined the structure of the rural economy, which consists of three main groups of sectors, including agricultural and non-agricultural economic activities, as well as the service sector. The first group consists of the agricultural activities, which include both traditional agricultural products and their forgotten types.

The second group consists of alternative activities to agriculture - they mainly include industry, construction, forestry, and handicraft production. The third group, the most relevant for rural areas, includes the provision of various services in the social sphere of the countryside.

Based on the theoretical principles of the diversified development of rural territories and the analysis that allowed identifying the conditions for the transition to rural diversification, the model of the diversified rural economy of the Voronezh region with sector-specific and multi-sectoral form was developed.

The sector-specific form of the rural economy is characterized by the concentration of all available resources in the territory in the priority industry, which allows obtaining the greatest effect from its development. The sector-specific form of the model combined 20 regions of the region with non-diversified economic structure, in which the share of one industry (agriculture, industry, or trade) in the total volume of production, sales, and services is more than $50.0 \%$, while agriculture can be either the core sector or virtually undeveloped. For this economy type the model is characterized by low diversification level and resource provision, employment ranges from 15.0 to $30.0 \%$, wages range from 25 to 37 thousand rubles.

Multi-sectoral form of the model is divided into 2 blocks:

- with slightly diversified economy structure;

- with diversified economy structure. 
The block with slightly diversified rural economy includes 6 districts, where one or two sectors occupy from 30.0 to $45.0 \%$ of the economy structure, and all the other sectors develop almost uniformly; employment rates range from $25.0 \%$ and higher; agriculture, most often, is one of the main sectors (with share of about 25.0-35.0 \% of the total production), the average monthly salary does not exceed 25 thousand rubles. The block with diversified rural economy includes 5 districts where the share of all types of activity in the total volume of production, sale, and services is approximately the same, and agriculture is effectively combined with other sectors of the economy. Employment rate exceeds $30 \%$. In $75.0 \%$ of the districts of this block, agriculture accounts for less than $30.0 \%$ of the total production, the moderate level of resource supply is detected. The average monthly salary is about 30 thousand rubles.

The results obtained allow stating that in some territories the process of transition to a multi-sectoral structure is only beginning, while in the others, on the contrary, the diversification of the rural economy is actively developing due to the organization of new alternative branches, industries, and sectors.

The performed grouping of the rural areas of the districts of the region shows that their presence in one group or another does not guarantee that they have both high diversification level and well-developed economic structure. This allows stating that the development is quite diverse, even within the same group. Thus, in almost every group there are areas with low and high levels of diversification. Such data indicate that in rural municipal districts with the low diversification indicator, local authorities consider the current structure of the economy to be optimal, while in the districts with the high indicator, on the contrary, they suggest the development of not only activities traditional for the countryside, but also alternative ones.

Therefore, based on the foregoing, for the model being developed, it is necessary to take into account the features of the development of each district through the application of such criteria as economic ones, the specific weight of each type of activity in the structure of the rural economy (agriculture, industry, trade, and services). Based on them the level of district development is assessed. Also the social criteria should be considered: the level of employment of the rural population, the average monthly wage, the standard of living of the population.

The importance of socio-economic criteria indicates that diversification is not only aimed at stimulating the economic development of the territory through the increase in the number of sectors, but also contributes to their social development through increasing employment of rural residents and their incomes.

The developed structural model of a diversified rural economy in the areas of the Voronezh region is shown in Figure 1. The model with a sector-specific form and a nondiversified structure of the rural economy includes $65.0 \%$ of rural municipal areas of the Voronezh region. The key advantage of this block is to maximize the benefits derived from the main sector, and the disadvantage is significant restrictions on maneuvering in the market due to a sharp reorientation of its activities. This model is divided into several groups, where the priority sector is identified: agriculture, industry, and trade. Let us consider each of them in more detail.

Buturlinovsky rural municipal district, where from 2014 to 2016 , the volume of sold agricultural products increased from 1,680 million rubles up to 2770 million rubles, can be distinguished in the group with agriculture as the priority sector. This fact indicates the growth in the yield of the main crops in the agricultural companies of the district and, as a result, the increase in the production. The structure of agricultural products sold is dominated by cereals $(23.0 \%)$, livestock and poultry (12.7\%), and sunflower (9.3\%).

The largest share in the structure of agricultural land is occupied by arable land, it accounts for $79.0 \%$, pastures $16.5 \%$, hayfields $-1.5 \%$, perennial plantations $-1.0 \%$.

In Anninsky rural municipal district, despite developed agriculture, industry occupies more than $50.0 \%$ in the structure of the rural economy. The investment climate of the Anninsky rural municipal district is one of the most attractive in the region. The advantages of the district are manifested through the convenient geographic location, the allocation of specialized sites for business development, high availability of qualified personnel, developed network of engineering and social infrastructure, roads and transport systems.

Only 2 districts fell into the group with trade as the priority sector. Let us consider Ramonskiy rural municipal district, where the predominant number of companies is occupied in wholesale and retail (24.6\% in the structure of the economy), as well as real estate companies, leasing, and other services $(15.0 \%)$. Also there are many organizations in the area of public administration and ensuring military security, social insurance $(12.0 \%)$

In this district's territory there are 396 retail objects carrying out trading activities. In the structure of retail trade, the turnover of food products in 2016 amounted to 7873 million rubles, the turnover of catering was 275 million rubles. In 2016, companies provided paid services worth of 2216 million rubles for the population, which is $6.4 \%$ more than in 2015 .

The model with multi-sectoral economy form includes the remaining $35.0 \%$ of rural municipal areas of the Voronezh region. The positive feature of such a model can be attributed to the fullest possible use of all available rural opportunities, as well as protection against sharp changes in the economy, while the disadvantage is decentralization of labor resources This block is also divided into several groups: with slightly diversified structure of the rural economy and diversified one. Consider each of them in more detail.

Among the districts with slightly diversified structure of the rural economy, the Ostrogozhskiy rural municipal district can be distinguished. Its economic potential is represented by large companies in the manufacturing industry and agriculture, the share of production taken by them in the economy structure is 35.7 and $38.1 \%$, respectively. 


\begin{tabular}{|c|c|c|c|c|}
\hline \multicolumn{5}{|c|}{ RURAL ECONOMY FORM } \\
\hline \multicolumn{3}{|c|}{ SECTOR-SPECIFIC } & \multicolumn{2}{|c|}{ MULTI-SECTORAL } \\
\hline \multicolumn{5}{|c|}{ RURAL ECONOMY STRUCTURE } \\
\hline \multicolumn{3}{|c|}{$\begin{array}{c}\text { UNDIVERSIFIED } \\
\text { the priority sector takes over } 50.0 \% \text { of the economy structure }\end{array}$} & \multirow{2}{*}{$\begin{array}{c}\text { SLIGHTLY DIVERSIFIED } \\
\text { one or two sectors take from } 30.0 \text { to } \\
45.0 \% \text { of the economy structure, } \\
\text { while all the others develop evenly }\end{array}$} & \multirow{2}{*}{$\begin{array}{l}\text { DIVERSIFIED } \\
\text { all sectors in the economy struc- } \\
\text { ture develop similarly }\end{array}$} \\
\hline agriculture & industry & trade & & \\
\hline \multicolumn{5}{|c|}{ DISTRICTS } \\
\hline $\begin{array}{l}\text { Buturlinovskiy, Berkh- } \\
\text { nemamonskiy, Vorobyev- } \\
\text { skiy, Nizhnedevitskiy, } \\
\text { Petropavlovskiy, Repyev- } \\
\text { skiy, Talovskiy, Ter- } \\
\text { novskiy }\end{array}$ & $\begin{array}{l}\text { Anninskiy, Bobrovskiy, Verkh- } \\
\text { nekhavskiy, Gribanovskiy, } \\
\text { Kashirskiy, Novokhoperskiy, } \\
\text { Ol'khovatskiy, Podgorenskiy, } \\
\text { Rossoshanskiy, Ertil'skiy }\end{array}$ & $\begin{array}{l}\text { Kamenskiy, } \\
\text { Ramonskiy }\end{array}$ & $\begin{array}{l}\text { Kalacheevskiy, Novousmanskiy, } \\
\text { Ostrogozhskiy, Pavlovskiy, } \\
\text { Povorinskiy, Khokhol'skiy }\end{array}$ & $\begin{array}{l}\text { Bogucharskiy, Kantemirovskiy, } \\
\text { Liskinskiy, Paninskiy, Semiluk- } \\
\text { skiy }\end{array}$ \\
\hline \multicolumn{5}{|c|}{ DESCRIPTION } \\
\hline $\begin{array}{l}\text { In these districts, due to } \\
\text { efficient agriculture, high } \\
\text { level of employment } \\
\text { (more than } 30.0 \% \text { ) and } \\
\text { average monthly wages } \\
\text { ( } 25 \text { thousand rubles) are } \\
\text { ensured. }\end{array}$ & $\begin{array}{l}\text { The processing of agricultural } \\
\text { products is well developed in } \\
\text { these districts, and the employ- } \\
\text { ment and wages of the rural } \\
\text { population are at an average } \\
\text { regional level ( } 28.0 \% \text { and } 26 \\
\text { thousand rubles, respectively). }\end{array}$ & $\begin{array}{l}\text { In these districts, the } \\
\text { basic sector is trade, } \\
\text { which ensures low } \\
\text { share of people } \\
\text { employed there } \\
\text { (15.0\%) with high } \\
\text { wages ( } 36.5 \text { thou- } \\
\text { sand rubles). }\end{array}$ & $\begin{array}{l}\text { These districts are characterized by } \\
\text { a combination of industry and agri- } \\
\text { culture or construction with an aver- } \\
\text { age level of employment ( } 25.0 \%) \text {, } \\
\text { and low average monthly wage ( } 23 \\
\text { thousand rubles). }\end{array}$ & $\begin{array}{l}\text { All sectors of the rural economy } \\
\text { are developing in these districts, } \\
\text { which makes it possible to } \\
\text { ensure high level of employ- } \\
\text { ment (over } 30.0 \% \text { ) and average } \\
\text { monthly wage ( } 26 \text { thousand } \\
\text { rubles). }\end{array}$ \\
\hline \multicolumn{5}{|c|}{$\begin{array}{l}\text { PRIORITY DEVELOPMENT DIRECTIONS } \\
\end{array}$} \\
\hline $\begin{array}{l}\text { Traditional agriculture, } \\
\text { services }\end{array}$ & Industry, construction, services & $\begin{array}{l}\text { Traditional agricul- } \\
\text { ture, industry, con- } \\
\text { struction, services }\end{array}$ & $\begin{array}{l}\text { Industry, construction, education, } \\
\text { healthcare, recreation }\end{array}$ & $\begin{array}{l}\text { Services, lost types of agriculture, } \\
\text { industry, construction. }\end{array}$ \\
\hline
\end{tabular}

Fig. 1. Structural model of the diversified economy of rural areas in the Voronezh region

The executives of the administrations of rural areas of the region who deal with the issues of rural development were selected as the experts for the assessment.

The obtained results were divided into the following groups:

- Group 1 - the most promising diversification development directions for the rural economy;

- Group 2 - promising diversification development directions for the rural economy;

- Group 3 - less promising diversification development directions for the rural economy;

- Group 4 - unpromising diversification development directions for the rural economy.

The expert assessment showed that the most promising areas were non-agricultural activities and the service sector. Therefore, under the modern conditions, the restructuring of the rural economy is possible due to its reorientation to the development of alternative activities to agriculture.

For each block of the developed model, the main directions have a different degree of significance for the rural economy. Thus, for areas with non-diversified rural economy, the most promising areas are traditional agriculture and the development of the service sector, undesirable ones include handicrafts, forestry, and lost types of agriculture [10].

The results of the expert assessment for the areas with slightly diversified rural economies showed the importance of industrial development, construction, education and health care, and recreation. Less important were the harvesting of resin gum; collection of wild plants and medicinal plants; forest beekeeping.
For the block with diversified structure of the rural economy, experts considered that all types of activities are significant for the development of rural areas to a certain degree.

\section{CONCLUSION}

The study of the various approaches to modeling the development of rural territories allows concluding that when building the model of rural territories, it is necessary to take into account the basic properties of the object of modeling, i.e. rural economy, which is a multi-structure economy based on a set of business entities, sectors, and activities related to the use of rural resources and employment.

In the course of the study, it was found that in the rural area economy of the Voronezh region, a rather large number of problems remain due to both the specifics of its sectoral structure and the peculiarities of the socio-economic development of the region.

At the same time, under the conditions of efficient use of the significant resource potential available in the region, as well as competent work of managers, it is quite possible to restructure the economy in such a way that would contribute to the achievement of economic growth and the solution of important social issues related to the provision of the rural population with jobs, providing employees with certain social guarantees, including raising wages.

The model of the diversified rural economy of the region has been developed, which takes into account the degree of prevalence of sectors in its structure and their various combinations: non-diversified economy - the priority sector occupies more than $50 \%$; slightly diversified - one or two industries make up from 30 to $45 \%$, and the rest develop 
evenly; diversified one - all industries are developing approximately the same way.

Based on the analysis of the sector-specific and multisectoral form of the rural economy of the Voronezh region, it was found that the most efficient is the multi- sectoral mode with diversified rural economy, the basis of which is the rational use of natural resource potential for the purpose of increasing the incomes and the use of various combinations of economic activities.

The prospective directions for restructuring the rural economy of the districts, according to the expert assessment, were substantiated, which made it possible to create a new structure taking into account alternative activities.

\section{References}

[1] L.M. Akimova, N.L. Khomiuk, I.M. Bezena et al., "Planning of socioeconomic development of the territories (Experience of European Union)", Int. J. of Manag., vol. 11, iss. 4, pp. 567-575, April 2020.

[2] L. Christiaensen, "Introduction: rural diversification, secondary towns and poverty reduction: do not miss the middle", Agricult. Econ., vol. 44 no. 4-5, pp. 433-434, Jule 2013.

[3] K.E. Corey, M.I. Wilson, M.J. Corey, A Model for Rural Development: An Experiment from Fogo Island, Paperback. Newfoundland, 2014, 242 p.

[4] S. Ella, R.N. Andari, "Developing A Smart Rural Model for Rural Area Development in Indonesia”, pp. 1-6, 2018 [Int. Conf. on ICT for Smart Society (ICISS)].

[5] R.U. Gusmanov, A.R. Kuznetsova, E.V. Stovba, M.R. Avzalov, "Newparadigm of the economic development of the regional rural territories", Europ. Proc. of Social and Behavioural Sci., vol. 59, pp. 206-217, December 2019 [International Scientific and Practical Conference on Contemporary Issues of Economic Development of Russia - Challenges and Opportunities (CIEDR), p. 1083, 2019].
[6] I. Hodge, P. Midmore "Models of Rural Development and Approaches To Analysis Evaluation And Decision-Making", Écon. Rurale, no. 307, p. $23-38,2008$.

[7] L. Kalachevska, "Models for innovation development of rural territories based on infrastructure development", Baltic J. of econ. stud., vol. 4, no. 1, pp. 175-180, March 2018.

[8] I. Merenkova, O. Smyslova, A. Kokoreva, "Development models of rural areas: theoretical approaches and formation specificity", IOP Conf. Ser. Earth and Environmental Sci., vol. 341, p. 012017, November 2019.

[9] O.V. Moroz, N.P. Karachyna, T.V. Vakar, A.V. Vitiuk, "Territorial branding as an instrument for competitiveness of rural development", Acad. J. of Interdisciplinary Stud., vol. 9, iss. 3, pp. 166-175, 10 May 2020.

[10] L. Naldi, P. Nilssonb, H. Westlund, S. Wixe, "What is smart rural development?", J. of Rural Stud., vol. 40, pp. 90-101, August 2015.

[11] G. Salchner, "Design of territories and management structures in regional and rural development", New challenges of economic and business development - 2017: digital economy, pp. 531-542, May 2017 [9th Int. Sci. Conf. on New Challenges of Econ. and Busin. Development - Digital Econ., p. 787, 2017].

[12] N.A. Serebryakova, I.V. Avdeev, "The content of structural transformations of the region's economy, adequate to the requirements of digitalization", Proc. of the Voronezh State Univer. of Engineer. Technol., vol. 80, no. 4, pp. 408-412, December 2018.

[13] J.S. Filho, G.M. Whitacker, "Models of rural development: the social and natural costs and studies of public sustainable management in Brazil", Latin Amer. J. of Manag. for Sustainable Development, vol. 1, no. 4, pp. 251-269, 2014.

[14] L. Yansui, Zh. Fugang, Zh. Yingwen, "Appraisal of typical rural development models during rapid urbanization in the eastern coastal region of China”, J. of Geogr. Sci., vol. 19m no. 5, pp. 557-567, 2009.

[15] V.G Zakshevsky, I.N. Merenkova, E.S. Kusmagambetova, I.I. Novikova, "Methodological Toolkit for Diagnosing the Diversification of Rural Economy", Econ. of reg., vol. 15, no. 2, pp. 520-533, June 2019. 